\title{
Methodology of the theory of change management in the implementation of digital transformation of construction: problems and prospects
}

\author{
Andrey Panenkov 1,", Inessa Lukmanova ${ }^{2}$, Irina Kuzovleva ${ }^{3}$, and Vladimir Bredikhin ${ }^{4}$ \\ ${ }^{1}$ Voronezh State Technical University, Moscow Avenue, 14, Voronezh, 394026, Russia \\ ${ }^{2}$ Moscow State University of Civil Engineering, Yaroslavskoe shosse, 26, Moscow, 129337, Russia \\ ${ }^{3}$ Bryansk State Engineering University, Stanke Dimitrova av., 3, 241037, Bryansk, Russia \\ ${ }^{4}$ Southwest State University, 50-letiya Oktyabrya, 94, 305040, Kursk, Russia
}

\begin{abstract}
The need for an innovative digital transformation of the construction industry is beyond doubt. However, it is fraught with a number of objective constraints, which requires the development of appropriate holistic science-based approaches and an effective practical methodology. Based on the systematization of the specifics of digitalization of the construction industry, analysis of the achieved level of innovative digital development, study of existing experience and institutional trends, the authors postulated a change management methodology as one of the key conceptual approaches to effective planning and management of digital transformation of construction. The life cycle of changes was modified on the basis of the design-process approach, and the corresponding practical assessment was carried out using the example of the implementation of information modeling technology in construction.
\end{abstract}

\section{Introduction}

Nowadays, the use of digital technologies in all sectors of the economy is a stable global trend, following which the Russian Federation adopted the National Program "Digital Economy of the Russian Federation" [1]. As a target for the construction digitalization strategy, it is postulated the creation of a single digital space for participants in urban planning activities at all stages of the life cycle of a capital construction object, which, given the certain inertia of the construction industry both in terms of innovation and in terms of digitalization, can only be achieved through system digital transformation of all business processes.

The specificity of digitalization in the construction industry is expressed in a number of aspects:

firstly, the complexity and uniqueness of investment and construction projects and construction objects, which complicates the unification of requirements;

\footnotetext{
* Corresponding author: andreyka.panenkov@mail.ru
} 
secondly, a large number of stakeholders throughout the life cycle of a construction object, which provokes communication difficulties, possible distortions in the transfer of information and different perceptions of the goals, methods and results of digitalization;

thirdly, the innovative inertia of the industry, generated by the multiplicity of regulatory sources and, often, their inconsistency;

fourthly, the existing variety of software and other technologies for automating the management of investment and construction projects, which leads to the practical impossibility of sharing digital tools;

fifthly, the fragmentation and incompleteness of numerous information systems containing information necessary in the implementation of construction investment projects, which creates "gaps" in information flows;

sixthly, the existence of a number of areas and plans for the digitalization of the industry, initiated at various levels of management, but not coordinated with each other, which leads to the absence of a single conceptual representation of both the planned result of digitalization itself and methods of achieving it.

In addition, the poly-subject nature of investment and construction projects, along with the multiplicity and complexity of the interconnections between them, leads not only to the existence of many information systems, but also to the need for their high-quality integration into a single digital space based on creating access for all project participants, ensuring the unity of the regulatory and technical documentation and classifiers, determining the format of structured information exchange, introducing digital technologies at different stages of the project, forming qualitatively new technological approaches to the interaction of all participants in investment and construction activities. Such digital interaction of project participants also requires a certain level of training of specialists who own not only digital project management tools, but are also capable of seeing the project as a whole, throughout its entire life cycle, in the interconnection of all stakeholders and types of work [2]. The goal of digitalization is to reduce construction time while improving the quality of management of erecting capital construction objects and making management decisions based on reliable and up-to-date data. It should be noted that the urgency of the problem of digitalization of the construction industry was emphasized at the level of the President and the Government of Russia.

\section{Materials and Methods}

The level of digitalization in construction is extremely low (Fig. 1), which is a consequence of the multiplicity of construction stakeholders with multidirectional interests and simultaneously involved in the implementation of an investment and construction project; a large number of necessary approvals and checks, accompanied by paper workflow; a long life cycle of the project, which is especially difficult to automate at the construction stage due to the presence of a large number of interconnected and sequential works that require various equipment and resources of a wide range. 


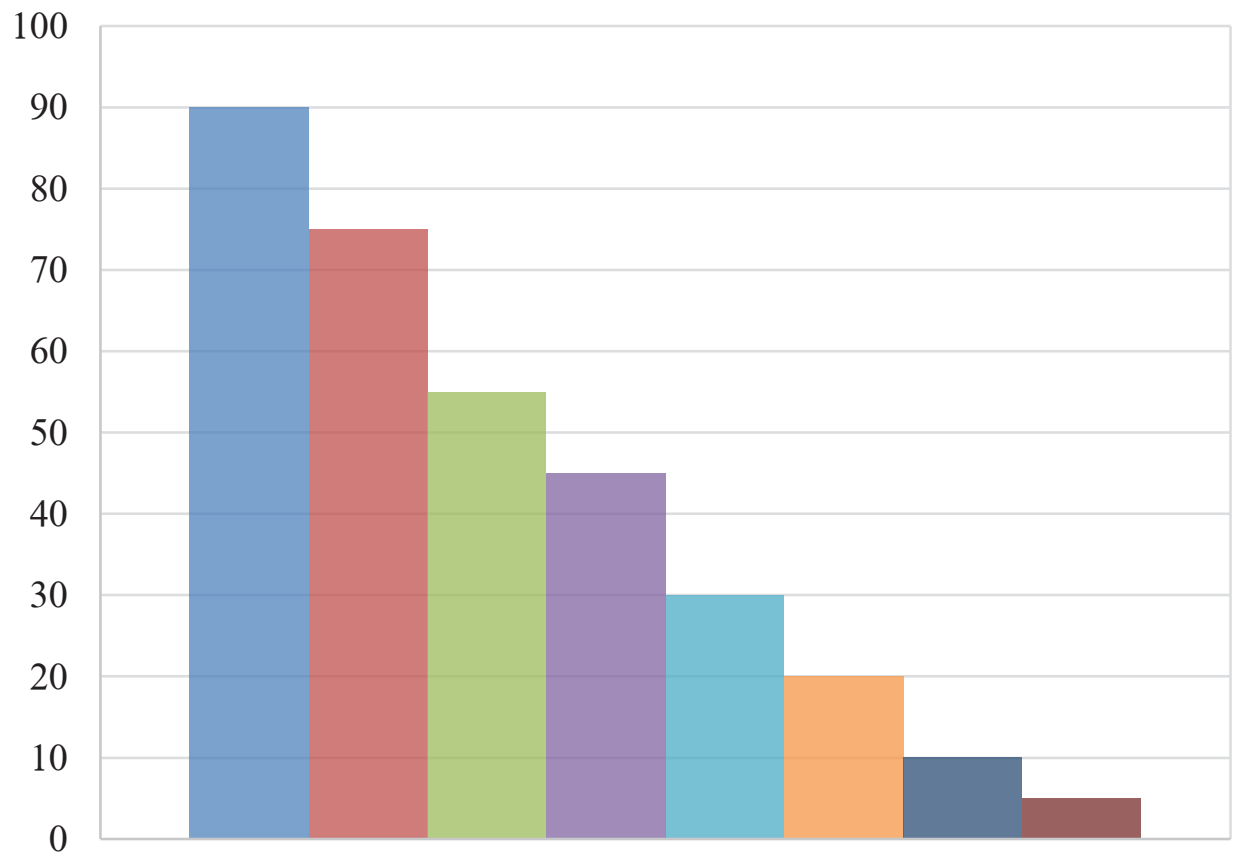

The level of digitalization of individual industries

Information and communication technologies

Media

Finance

Oil, gas

Education

Health care

- Construction

- Agricultural industry

Fig. 1. The level of digitalization of the sectors of the Russian economy (compiled on the basis of [3])

We consider it necessary to single out innovation as the most important area of digitalization in construction. In accordance with the principle of innovation and the "changeinnovation" circuit [4], technical and technological innovations in construction are the source and catalyst of digital transformation, while being one of the elements of this transformation. In general, the main areas of digitalization of construction can be represented in the form of a diagram (Fig. 2). 


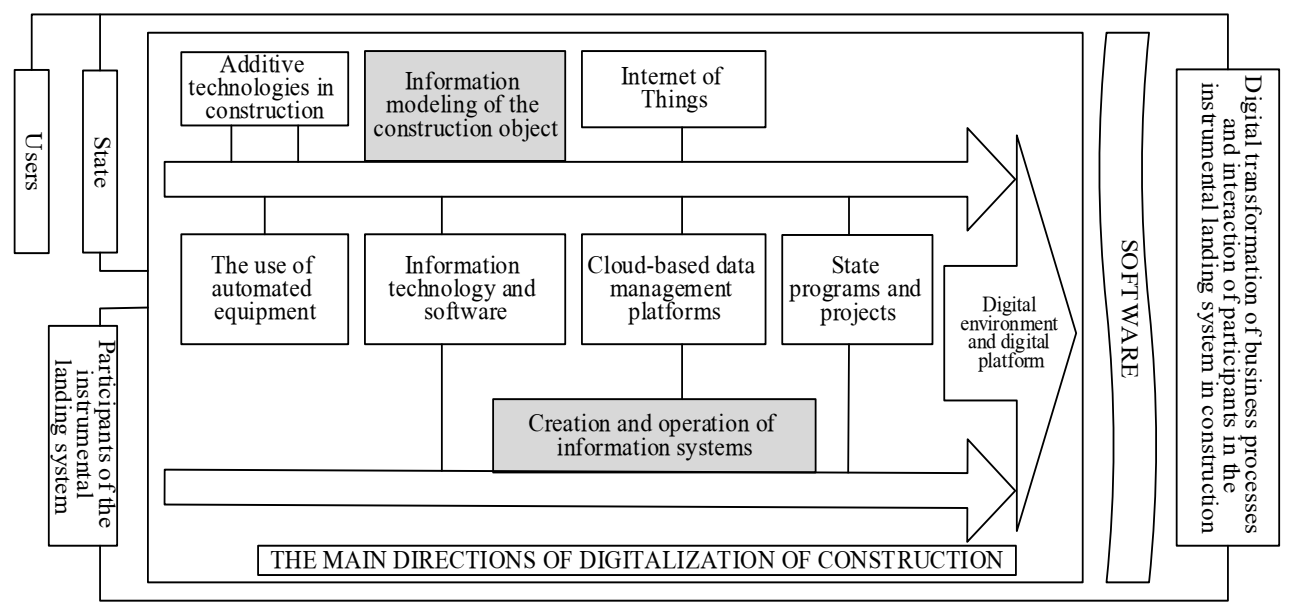

Fig. 2. The scheme of formation of areas of digitalization in construction

For the purposes of this study, we consider it necessary to discuss the concept of digitalization in both a narrow and a broad sense. In a narrow sense, the key elements of the concept are the transformation of information into digital form [5]. In a broad sense, digitalization is synonymous with the concept of digital transformation as a transformation of all elements of the system (in this case, the management system of the investment and construction complex) for the purpose of sustainable economic development within the framework of a new technological order and sustainable development of territories [6]. Accordingly, the effects of digital transformation should be considered compliance with the principles of sustainable development of territories [7] and sustainable development in general [8].

The above conclusions allow interpreting both digitalization and digital transformation from the standpoint of the theory of change, since the key elements of the concept of change are constant continuous movement and interaction of system elements; differentiated movement on the basis of reversibility, initiation and orientation; change of the qualitative state with the possibility of its quantitative measurement. Based on the perception of digitalization and digital transformation as changes, we consider it possible and expedient to manage digitalization processes by digital transformation based on the methodology of the theory of change [9].

\section{Results}

In general, the conceptual foundations of digital transformation in construction from the perspective of the theory of change are presented in the form of a diagram (Fig. 3). 


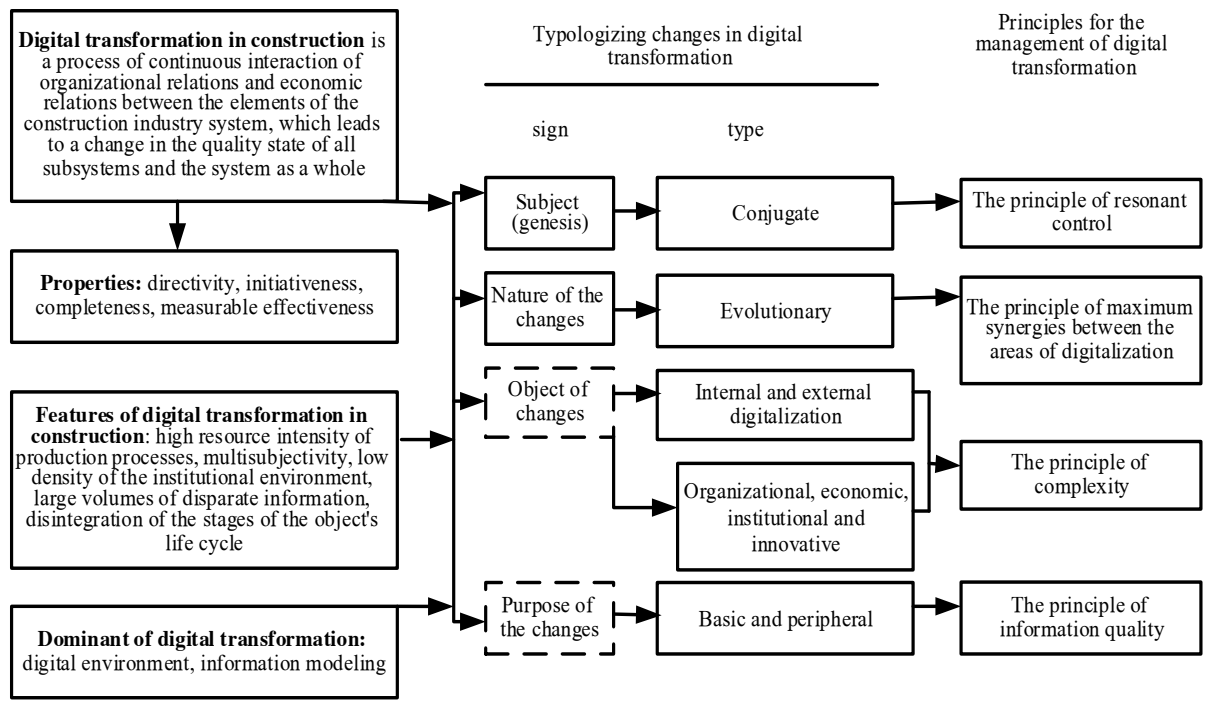

Fig. 3. Conceptual foundations of digital transformation in construction from the perspective of the theory of change

It is also necessary to postulate the principle of fractality of the construction management system. If we consider public administration as a control subsystem, the controlled system is characterized by large-scale invariance, and the functions and management methods are similar at all levels of management, which gives rise to the conclusion about the fractality of the construction management system: public administration (macro level), sectoral management (meso level), enterprise management (micro level), project management [10]. Accordingly, within the framework of goal-setting for changes in the digital transformation of construction, the main task of management is to create conditions for digital transformation at the level of investment and construction projects.

Each of the areas of digitalization usually contains a number of different-level spontaneous initiatives and initiated changes. The implementation of the initiated changes can be presented as a project, since when initiating a change, the goal is focused, to which the result of the changes must correspond.

It should be noted that discrete projects will not create a complete digital transformation. Therefore, change projects must be carried out constantly, forming a portfolio of projects characterized by polydynamics and conglomeration [8]. According to the methodology of scheduling and network planning within each project, it is possible to distinguish in the process of performing certain types of work [11], which leads to the expediency of considering changes from the point of view of both project and process approaches.

Researchers identify a certain staging in the process of change. The classical model of Kurt Lewin postulates the presence of three stages in the process of organizational change: unfreezing of the existing state, movement towards a new changed state, stabilization and freezing of a new state.

In connection with the acceleration of the processes of changes in the modern economy, the necessity and very existence of the "freezing" stage in the life cycle of changes is questioned by a number of researchers. However, other researchers distinguish a certain period necessary for the awareness and acceptance of the new situation that has developed as a result of changes, both at the level of the organization [12-14] and at the level of the socioeconomic system as a whole. We consider it expedient to single out the stage of "freezing" in the life cycle of changes, which is necessary for analyzing the results and feasibility of 
changes, for accepting the object of changes in its results, as well as for reflection on the implementation of projects of changes, but not as the end of the transformation process, but as elements of monitoring with the purpose of identifying and adjusting further projects and change processes according to the spiral development model.

We believe that changes in any soco-economic system, including construction, occur constantly and represent a cyclical iterative process of implementing a number of projects of initiated changes and self-organization processes, expressed in the form of spontaneous changes, of varying intensity, sequence, target focus, predictability, and effectiveness, depending on the stage of development of the system (evolutionary and revolutionary). Since each change forms a complex system of interconnection, mutual influence and interdependence with other changes at different levels of the management system, then, as a result of any change, almost every aspect of the economic system (and not only the construction industry, but also related industries and complexes) undergoes one or another transformation.

In the life cycle, it is possible to distinguish a number of projects characterized by conglomeration and polydynamics, representing the implementation of initiated changes, as well as a number of vectors of spontaneous changes that are a consequence of the process of self-organization of the control system.

It should be noted that the projects of changes consist of a set of processes, which it is advisable to subdivide into six main groups that implement certain management functions. The enlarged process of organizational and economic changes, which, in turn, consists of a number of projects, is shown in Figure 5.

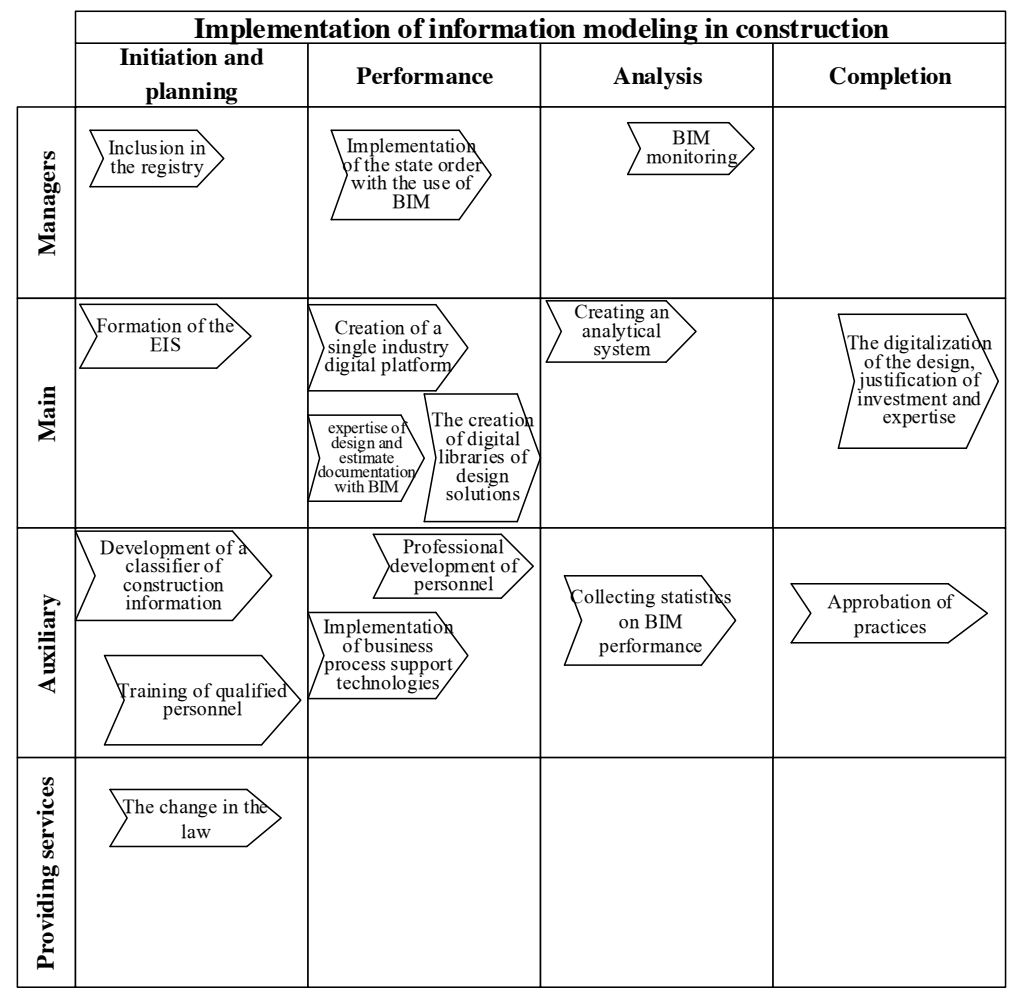

Fig. 5. The process of changes associated with the implementation of information modeling in construction 
Based on the results of a retrospective analysis of regulatory documents in the field of regulation of the construction industry in the process of transition to digitalization, as well as statistical and analytical information, we have made a characteristic of the enlarged processes of the project for the implementation of information modeling in construction (Table 1).

Table 1. Description of the enlarged processes of the project "Implementation of information modeling in construction".

\begin{tabular}{|c|c|c|c|}
\hline $\begin{array}{l}\text { Process } \\
\text { type }\end{array}$ & Process & $\begin{array}{c}\text { Time frame } \\
\text { of the } \\
\text { process }\end{array}$ & $\begin{array}{l}\text { Content characterization and process } \\
\text { performance monitoring }\end{array}$ \\
\hline \multirow[t]{2}{*}{$\begin{array}{l}\text { Managem } \\
\text { ent }\end{array}$} & $\begin{array}{ll}\text { Design } & \text { information } \\
\text { modeling } & \end{array}$ & $\begin{array}{l}\text { Beginning } \\
\text { in 2000, } \\
\text { 2014-up to } \\
\text { now }\end{array}$ & $\begin{array}{l}2000 \text { - introduction of information } \\
\text { modeling technologies in the design of } \\
\text { construction projects. } \\
2015-2016 \text { - BIM pilot projects. In } \\
2019,22 \% \text { of organizations use BIM in } \\
\text { their activities. } \\
2014 \text { - A plan for the phased } \\
\text { introduction of information modeling } \\
\text { technologies in the field of industrial and } \\
\text { civil construction. }\end{array}$ \\
\hline & BIM monitoring & $\begin{array}{l}2016-\text { up to } \\
\text { now }\end{array}$ & $\begin{array}{l}\text { Report on the effectiveness of the use of } \\
\text { BIM technologies in investment and } \\
\text { construction projects of Russian } \\
\text { companies (MGSU), based on a survey } \\
\text { of construction companies }\end{array}$ \\
\hline Main & Formation of the UIS & $\begin{array}{l}\text { Beginning } \\
\text { in } 2011 \text {, in } \\
\text { fact - from } \\
2018 \text { to the } \\
\text { present }\end{array}$ & $\begin{array}{l}\text { Since } 2011 \text {, the Town Planning Code } \\
\text { has a norm on the possibility of sending } \\
\text { documents for the issuance of a building } \\
\text { permit and a permit for putting objects } \\
\text { into operation in electronic form. } \\
2017 \text { - FSIS PiC. Data registration is } \\
\text { carried out by } 30 \% \text { of officially } \\
\text { registered manufacturers. } 12 \% \text { of } \\
\text { materials are registered. } \\
2017 \text { - } 3 \text { constituent entities of the } \\
\text { Russian Federation are implementing a } \\
\text { pilot project to transfer the procedures } \\
\text { for providing technical specifications } \\
\text { into electronic form. About } 4.5 \text { thousand } \\
\text { applications were received. } \\
2018 \text { - SIS USRC is functioning, it } \\
\text { contains more than } 26,000 \text { conclusions. } \\
2018 \text { - register of cost-effective project } \\
\text { documentation }\end{array}$ \\
\hline Main & $\begin{array}{l}\text { Expertise of design and } \\
\text { estimate documentation } \\
\text { with BIM }\end{array}$ & $\begin{array}{l}\text { Beginning } \\
\text { in } 2014\end{array}$ & $\begin{array}{l}2014 \text { - the first examination of a BIM } \\
\text { project. } \\
\text { Since } 2017 \text {, project documentation and } \\
\text { (or) engineering survey results are } \\
\text { submitted in electronic form. } \\
2018 \text { - SIS USRC is functioning }\end{array}$ \\
\hline \multirow[t]{2}{*}{ Auxiliary } & $\begin{array}{l}\text { Development of a } \\
\text { construction } \\
\text { information classifier }\end{array}$ & $\begin{array}{l}2019-\text { up to } \\
\text { now }\end{array}$ & $\begin{array}{l}\text { The structure of the classifier of } \\
\text { construction information has been } \\
\text { developed }\end{array}$ \\
\hline & $\begin{array}{l}\text { Collecting statistics on } \\
\text { BIM performance }\end{array}$ & $\begin{array}{l}2016-\text { up to } \\
\text { now }\end{array}$ & $\begin{array}{l}\text { Report on the effectiveness of the use of } \\
\text { BIM technologies in investment and } \\
\text { construction projects of Russian }\end{array}$ \\
\hline
\end{tabular}




\begin{tabular}{|l|l|l|l|}
\hline $\begin{array}{c}\text { Process } \\
\text { type }\end{array}$ & \multicolumn{1}{|c|}{ Process } & $\begin{array}{l}\text { Time frame } \\
\text { of the } \\
\text { process }\end{array}$ & \multicolumn{1}{|c|}{$\begin{array}{c}\text { Content characterization and process } \\
\text { performance monitoring }\end{array}$} \\
\hline $\begin{array}{l}\text { Supportin } \\
\mathrm{g}\end{array}$ & $\begin{array}{l}\text { Development of a } \\
\text { regulatory and technical } \\
\text { base for the } \\
\text { implementation of } \\
\text { information modeling in } \\
\text { construction, changes in } \\
\text { legislation }\end{array}$ & $\begin{array}{l}\text { now - up to } \\
\text { of construction companies }\end{array}$ & $\begin{array}{l}\text { A package of normative technical } \\
\text { documents for information modeling } \\
\text { was developed and approved, including }\end{array}$ \\
\hline
\end{tabular}

Planning and implementation of changes in the management system of the construction industry through its digitalization in accordance with the proposed life cycle of changes will contribute to ensuring the integrity and complexity of the planned transformation based on the advanced development of institutions.

The main changes initiated by the state on the implementation of information modeling of the life cycle management system for construction objects, including the digitalization of the industry, are included in the structure of the activities of the National Program "Digital Economy". The implementation of the relevant organizational and economic changes, in accordance with the principle of innovation, contributes to the development of selforganization mechanisms of the management system to stimulate the development of innovative software and the implementation of innovations in construction.

\section{Discussions}

The creation of a single digital space in construction and housing and communal services is an important complex task, the need to solve which was confirmed in the conditions of selfisolation. The low rates of digitalization in the construction industry are objectively determined by the specifics of both the industry itself (in technological, economic and institutional terms) and the facilities being created, and investment and construction projects.

The scientific significance of the work is determined by the need to systematize the theoretical basis of the digital transformation of the construction industry, clarify the principles of its implementation in order to intensify the digitalization process, build a sequence of steps for implementing this process at various levels of management, corresponding to the problems to be solved and the goals set.

The digitalization of construction implies the development of requirements and the definition of a methodology, as well as regulations for the interaction of all participants in the process. At the same time, competently developed requirements for the exchange of information will allow companies at various stages of the project to work in different solutions, while coming at a single result of improving the quality of construction products while reducing the cost of their production.

\section{Conclusion}

Based on the results of analytics and systematization of the environment of digitalization in construction, it should be concluded that digitalization of construction in the narrow sense has a low rate of development. At the same time, both organizational, economic, and innovative, institutional parameters act as conditions and factors for digitalization and digital transformation. Therefore, it is necessary to develop methods for managing digital transformation in construction based on a change management methodology that combines 
the above types of parameters, which makes it possible to increase the positive dynamics of digitalization in order to ensure targeted focusing of improving the efficiency and quality of the implementation of an investment and construction project and its result within the framework of the concept of sustainable development.

\section{References}

1. The program for the development of the digital economy in the Russian Federation until $2035 \mathrm{http}: / /$ spkurdyumov.ru/uploads/2017/05/strategy.pdf (Last accessed 10.12.2020)

2. S. Belyaeva, O. Belyantseva, N. Safonova, O. Vasilyeva, E3S Web of Conferences, 33, 03021 (2018)

3. Digital Russia: New Reality. July 19, 2017 McKinsey Global Institute http://www.tadviser.ru/images/c/c2/Digital-Russia-report.pdf (Last accessed 14.12.2020)

4. K. Gumba, S. Revunova, S. Uvarova, S. Belyaeva, MATEC Web of Conferences, 08023 (2017)

5. A. N. Kozyrev, http://digital-economy.ru/stati/tsifrovaya-ekonomika-i-tsifrovizatsiya-vistoricheskoj-retrospektive (Last accessed 14.12.2020)

6. What digital transformation means https://www.infoworld.com/article/3080644/what-digital-transformation-reallymeans.html (Last accessed 14.12.2020)

7. United Nations Program on Human Settlements (UN-Habitat) https://www.un.org/ru/ga/habitat/ (Last accessed 24.12.2020)

8. V. S. Kankhva, S. S. Uvarova, S. V. Belyaeva, Procedia Engineering, 165, 1046-1051 (2016)

9. K. Gumba, S. Revunova, S. Uvarova, S. Belyaeva, MATEC Web of Conferences, 08023 (2017)

10. Ya. Rogacheva, A. Panenkov, Z. Petrikova, E. Nezhnikova, E3S Web of Conferences, 03037 (2018)

11. S. D. Reznik, O. V. Kholkina, Economics of Construction, 1(55), 44-60 (2019)

12. R. Lozano, B. Nummert, K. Ceulemans, Original Research Article Journal of Cleaner Production, 125, 168-188 (2016)

13. I. Ilin, V. Vasilenok, R. Marchenko, Use of renewable energy and tax burden on CO2 emissions in industrial enterprises, E3S Web of Conferences, 110, 0210 (2019)

14. I. Ilin, A. Levina, O. Iliashenko, Enterprise Architecture Analysis for Energy Efficiency of Saint-Petersburg Underground Advances in Intelligent Systems and Computing, 692, 1214-1223 (2018) 